\title{
Chemical Characterization of Soil with Superficial Application of Avian Bed in Succession to Canola Cultivation
}

\author{
A. G. C. C. Daronch ${ }^{1}$, T. P. Chiapetti ${ }^{1}$, L. K. Rinaldi ${ }^{1}$, J. de A. Barbosa ${ }^{1}$, G. Ritter ${ }^{1}$, M. E. L. Rocha ${ }^{1}$, \\ M. T. R. Abade ${ }^{1}$, C. Hendges ${ }^{1}$, G. Mascarello ${ }^{1}$, C. Lubian ${ }^{1}$, M. Javorski ${ }^{2} \&$ I. Perego ${ }^{1}$ \\ ${ }^{1}$ Department of Plant Production, State University of the West of Paraná, Marechal Cândido Rondon, Brazil \\ ${ }^{2}$ Department of Plant Production, University Center FAG, Cascavel, Brazil \\ Correspondence: Tatiane Priscila Chiapetti, Department of Plant Production, State University of the West of \\ Paraná, Rua Pernambuco, 1777, Marechal Cândido Rondon, Brazil. Tel: 55-45-3284-7911. E-mail: \\ tatianechiapetti@gmail.com
}

Received: June 27, 2017

Accepted: July 28, $2017 \quad$ Online Published: September 15, 2017

doi:10.5539/jas.v9n10p220

URL: https://doi.org/10.5539/jas.v9n10p220

\begin{abstract}
Additions of poultry manure can promote improvements in the conditioning of the biological, physical and chemical properties of the soil. Thus, the present study aimed to evaluate soil chemical attributes through the superficial application of linear doses of chicken litter. The experimental design was a randomized block design, with 4 replicates and 7 treatments: T1: Witness (without application of avian bed), T2: $1 \mathrm{Mg} \mathrm{ha}^{-1}, \mathrm{~T} 3: 2 \mathrm{Mg} \mathrm{ha}^{-1}$, T4: $4 \mathrm{Mg} \mathrm{ha}^{-1}$, T5: $8 \mathrm{Mg} \mathrm{ha}^{-1}$, T6: $16 \mathrm{Mg} \mathrm{ha}^{-1}, \mathrm{~T} 7: 32 \mathrm{Mg} \mathrm{ha}^{-1}$ avian bed. The results indicate that the application of avian bed doses has an influence on $\mathrm{K}^{+}$results, where intermediate doses as 12 and 18 ton ha ${ }^{-1}$ have higher results in potassium content in the analyzed soil. The doses of aviary bed alter the total organic carbon content. It can be said that higher doses of avian bed result in higher values of phosphorus and calcium. The calcium contents were higher than the magnesium content, potential acidity $\left(\mathrm{H}^{+}+\mathrm{Al}^{3+}\right)$ and Sulfur had a similar behavior to that of Calcium and Magnesium, a negative quadratic behavior. The values for $\mathrm{pH}$ measured did not vary greatly in relation to the doses of poultry bed applied and from the statistical data it was possible to determine that only $\mathrm{pH}_{\mathrm{CaCl}}$ had a significant difference. All other chemical attributes analyzed were not significantly influenced by the addition of the organic fertilizer when compared to the control, regardless of the application form in the soil.
\end{abstract}

Keywords: organic fertilization, soil fertility, chicken waste

\section{Introduction}

In the last decades, the Brazilian poultry industry showed a high growth rate, becoming the third largest producer in the world, counting on a herd of 5.5 billion heads of cutting and laying chicken, besides being the leader in exports (IBGE, 2010). In view of this, more and more alternatives are being sought for the safe use of chicken waste to avoid contamination of the environment. The use of these organic wastes in agriculture as a source of nutrients for crops becomes an interesting alternative in view of the high price of fertilizers, combined with the low cost of production, since it can be generated within the rural property. The avian manure is rich in nutrients, with emphasis on nitrogen, phosphorus and potassium nutrients, which have a high demand for plants and microorganisms. Its application has been associated to the improvements in the chemical, physical and biological attributes of the soil, contributing to the reduction of erosion, increased water retention, Improvement in the biological quality of the soil, and increased carbon and nitrogen contents (Bayer, Martin-Neto, Mielniczuk, \& Pavinat, 2004; Costa, Borges, Silva, \& Guimarães, 2009). Melo et al. (2011) point out that organic fertilization with avian waste also provides greater recycling of nutrients in the soil by plants when compared to mineral fertilization.

Silva et al. (2012) evaluated the use of different sources of nutrients (chicken litter, turkey litter, swine manure and mineral fertilization) in a dystrophic Red Latosol under degraded pasture, and observed that in areas with organic fertilization in the $0.0-0.20 \mathrm{~m}$, there was an increase in phosphorus and potassium contents. Costa et al. (2009) found that the use of increasing doses of pastureland, there are increases in aggregates larger than $2.0 \mathrm{~mm}$ and a reduction of aggregates smaller than $0.25 \mathrm{~mm}$, contributing to soil density and total porosity. 
Canola (Brassica napus L.) is a nutritionally demanding plant, requiring large amounts of nitrogen and sulfur. However, deficiency of these nutrients is frequent in soils with acidic or low organic matter content.

Considering that canola is a plant that causes differences in soil nutrition, it is interesting to apply avian waste in previously cultivated soil with canola to evaluate soil chemical quality and verify possible soil changes. This will allow you to make predictions about which crops to use in the succession of canola, or even how to proceed before and after cultivation.

In this context, the verification of the potential fertilization of avian litter in agricultural areas may influence the correct decision making of the destination of this organic residue (Krob, 2011). With the application of this residue in the soil, it is sought to match, or even surpass, the grain yield of the crops obtained with the use of chemical fertilizers, which can reduce the productive costs. Based on these considerations, the present work aimed to evaluate the effects of the application of linear doses of avian litter on the chemical attributes of a Red Latosol.

\section{Material and Methods}

The experiment was conducted on a private property in the municipality of Serranópolis do Iguaçu, state of Paraná (latitude $25^{\circ} 22^{\prime} \mathrm{S}$, longitude $54^{\circ} 03^{\prime} \mathrm{W}, 325 \mathrm{~m}$ amsl). According to the climatic classification of Köppen (1931), the local climate is defined as humid subtropical (Cfa), characterized by hot summer without dry season.

The soil of the area is classified as Red Latosol eutroferric, with a very clayey texture, being the sand, silt and clay contents of $9.85 \%, 13.50 \%$ and $76.65 \%$, respectively. It is noteworthy that in the study area, soybean (Glycine max L.) crops are traditionally grown in the summer, and corn (Zea mays L.) or wheat (Triticum aestivum L.) in winter.

The chemical analysis of the soil in the layers of 0 to $0.2 \mathrm{~m}$ and 0.21 to $0.40 \mathrm{~m}$, before the implantation of the experiment, are described in Table 1. The analyses were carried out in the year 2016.

Table 1. Chemical attributes of the soil, before the implementation of the experiment, Serranópolis do Iguaçu-PR

\begin{tabular}{|c|c|c|c|c|c|c|c|c|c|c|c|c|c|}
\hline Layer & S & $\mathbf{P}$ & O.M. & $\mathbf{p H}_{\mathrm{CaCl}_{2}}$ & $\mathbf{H}+\mathbf{A l}$ & $\mathbf{A l}^{3+}$ & $\mathbf{K}^{+}$ & $\mathrm{Ca}^{2+}$ & $\mathbf{M g}^{2+}$ & SB & CTC & V & Al \\
\hline --- m --- & $--\mathrm{mg} \mathrm{dm}^{-3}-$ & $--\mathrm{mg} \mathrm{dm}^{-3}--$ & $--\mathrm{g} \mathrm{dm}^{-3}--$ & & ------- & ----- & ------ & cmolc & $\mathrm{dm}^{-3}-$ & ----- & --------- & ------ & 0 ----- \\
\hline $0-0.2$ & 4,25 & 27.04 & 26.22 & 5.22 & 2.95 & 0.00 & 0.41 & 4.25 & 1.72 & 6.38 & 9.33 & 68.38 & 0.00 \\
\hline $0.2-0.40$ & 3.54 & 9.80 & 13.13 & 4.92 & 5.35 & 0.12 & 0.28 & 3.54 & 1.1 & 4.92 & 10.27 & 47.91 & 1.17 \\
\hline
\end{tabular}

In order to carry out the experiment, Hyola 433 hybrid canola was sown in May 2016 and harvested in September 2016, totaling a cycle of 145 days. The line spacing used was $0.5 \mathrm{~m}$, resulting in a density of 400000 ha ${ }^{-1}$ plants.

The avian bed used for the experiment was removed after the production of six batches of chicken, consisting of poultry residues and materials that are used for handling between the batches intervals, such as shavings and virgin lime.

The material was exposed to the environment for decomposition for a period of 60 days before applying it to the soil. A sample of the material was removed for analysis at the time of application to the soil in order to know the chemical composition of the organic fertilizer (Table 2).

Table 2. Chemical characterization of the litter bed used

\begin{tabular}{|c|c|c|c|c|c|c|}
\hline $\mathbf{N}$ & $\mathbf{P}$ & $\mathbf{K}$ & $\mathbf{C a}$ & Mg & $\mathbf{S}$ & M.O. \\
\hline ---" & -- & & 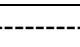 & & & \\
\hline 3,23 & 3,45 & 3,86 & 4,24 & 1,31 & 0,85 & 73,23 \\
\hline
\end{tabular}

The experimental design was a completely randomized block design, with four replications, in plots of $13.72 \mathrm{~m}^{2}$ of useful area $(7.5 \mathrm{~m} \times 4.5 \mathrm{~m})$. Seven treatments were used for the doses of avian bed, being these: i) $0 \mathrm{Mg} \mathrm{ha}^{-1}$; ii) $1 \mathrm{Mg} \mathrm{ha}^{-1}$; iii) $2 \mathrm{Mg} \mathrm{ha}^{-1}$; iv) $4 \mathrm{Mg} \mathrm{ha}^{-1}$; v) $8 \mathrm{Mg} \mathrm{ha}^{-1}$; vi) $16 \mathrm{Mg} \mathrm{ha}^{-1}$; and, vii) $32 \mathrm{Mg} \mathrm{ha}^{-1}$.

The doses of avian bed were manually applied to the surface without incorporation, three days prior to sowing. After the harvest, for each plot, disturbated soil samples were collected at five points in the soil surface layer from 0 to $0.2 \mathrm{~m}$, to evaluate the following chemical attributes: $\mathrm{pH}$ in $\mathrm{CaCl}_{2}, \mathrm{pH}$ in SMP, potential acidity $(\mathrm{H}+$ 
Al), Phosphorus (P), Potassium (K), Calcium (Ca), Magnesium (Mg), Sulfur (S), Carbon (C) and Organic matter (OM). The determination of the chemical attributes was performed according to the methodology described by Silva and Bohnen (2009).

The data were submitted to analysis of variance, the mean test and the regression analysis. In the analysis of variance the $\mathrm{F}$ test was used at the level of up to $5 \%$ probability. The averages were compared using the Tukey test at $5 \%$ probability. The regression models was chosen based on the significance of the regression coefficients using the t test at a level of up to $10 \%$, the coefficient of determination and the process under study. Statistical analyzes were performed using the SISVAR software (Ferreira, 2008).

\section{Results and Discussion}

Table 3 shows the chemical attributes of the soil for the different doses of avian bed applied.

Table 3. Mean values of the chemical attributes of an Eutrophic Red Latosol, for different amounts of avian bed, Serranópolis do Iguaçu-PR

\begin{tabular}{|c|c|c|c|c|c|c|c|}
\hline \multirow{2}{*}{ Attributes } & \multicolumn{7}{|c|}{ Amonts of avian bed $\left(\mathrm{Mg} \mathrm{ha}^{-1}\right)$} \\
\hline & 0 & 1 & 2 & 4 & 8 & 16 & 32 \\
\hline $\mathrm{pH}$ in water & $5.75 \mathrm{a}$ & $5.35 \mathrm{a}$ & $5.57 \mathrm{a}$ & $5.45 \mathrm{a}$ & $5.49 \mathrm{a}$ & $5.52 \mathrm{a}$ & $5.77 \mathrm{a}$ \\
\hline $\mathrm{pH} \mathrm{CaCl}{ }_{2}$ & $5.22 \mathrm{a}$ & $5.05 \mathrm{a}$ & $5.16 \mathrm{a}$ & $5.09 \mathrm{a}$ & $4.93 \mathrm{a}$ & $5.04 \mathrm{a}$ & $5.30 \mathrm{a}$ \\
\hline pH SMP & $5.95 \mathrm{~b}$ & $5.90 \mathrm{~b}$ & $5.93 b$ & $5.93 \mathrm{~b}$ & $6.28 \mathrm{a}$ & $6.13 \mathrm{ab}$ & $6.10 \mathrm{ab}$ \\
\hline $\mathrm{H}+\mathrm{Al}\left(\mathrm{cmol}_{\mathrm{c}} \mathrm{dm}^{-3}\right)$ & $5.16 a b$ & $5.36 \mathrm{a}$ & $5.26 \mathrm{a}$ & $5.22 \mathrm{ab}$ & $4.05 \mathrm{~b}$ & $4.54 \mathrm{ab}$ & $4.63 \mathrm{ab}$ \\
\hline $\mathrm{P}\left(\mathrm{mg} \mathrm{dm}^{-3}\right)$ & $47.85 \mathrm{a}$ & $51.28 \mathrm{a}$ & $38.80 \mathrm{a}$ & $49.75 \mathrm{a}$ & $38.58 \mathrm{a}$ & $45.10 \mathrm{a}$ & $53.42 \mathrm{a}$ \\
\hline $\mathrm{C}\left(\mathrm{g} \mathrm{dm}^{-3}\right)$ & $11.66 \mathrm{bc}$ & $11.58 \mathrm{bc}$ & $10.86 \mathrm{bc}$ & $9.82 \mathrm{bc}$ & $19.09 \mathrm{a}$ & $13.88 b$ & $8.15 \mathrm{c}$ \\
\hline $\mathrm{K}\left(\mathrm{cmol}_{\mathrm{c}} \mathrm{dm}^{-3}\right)$ & $0.50 \mathrm{ab}$ & $0.45 \mathrm{ab}$ & $0.44 \mathrm{~b}$ & $0.46 \mathrm{ab}$ & $0.64 \mathrm{a}$ & $0.61 \mathrm{ab}$ & $0.60 \mathrm{ab}$ \\
\hline $\mathrm{Ca}\left(\mathrm{cmol}_{\mathrm{c}} \mathrm{dm}^{-3}\right)$ & $5.32 \mathrm{a}$ & $4.87 \mathrm{ab}$ & $5.18 \mathrm{ab}$ & $4.88 \mathrm{ab}$ & $4.05 \mathrm{~b}$ & $4.56 \mathrm{ab}$ & $5.58 \mathrm{a}$ \\
\hline $\mathrm{Ca}+\mathrm{Mg}\left(\mathrm{cmol}_{\mathrm{c}} \mathrm{dm}^{-3}\right)$ & 7.63ab & 7.73ab & 7.10ab & $7.00 \mathrm{ab}$ & $5.40 \mathrm{~b}$ & $6.45 \mathrm{ab}$ & $8.00 \mathrm{a}$ \\
\hline $\operatorname{Mg}\left(\mathrm{cmol}_{\mathrm{c}} \mathrm{dm}^{-3}\right)$ & $2.30 \mathrm{a}$ & $1.95 \mathrm{ab}$ & $1.93 \mathrm{ab}$ & $2.13 \mathrm{ab}$ & $1.35 \mathrm{~b}$ & $1.89 \mathrm{ab}$ & $2.43 \mathrm{a}$ \\
\hline $\mathrm{S}\left(\mathrm{mg} \mathrm{dm}^{-3}\right)$ & $17.18 \mathrm{a}$ & $23.98 \mathrm{a}$ & $14.07 \mathrm{a}$ & $26.70 \mathrm{a}$ & $13.18 \mathrm{a}$ & $17.44 \mathrm{a}$ & $17.21 \mathrm{a}$ \\
\hline
\end{tabular}

Note. Means followed by the same letter in the line do not differ from each other, by the Tukey test $(\mathrm{p}<0.05)$.

As for $\mathrm{pH}$, it can be observed that the values were higher for water and calcium chloride and did not present significant difference between the different doses applied and canola cultivation. The $\mathrm{pH}$ in SMP was significantly different between doses, being higher (more basic) for the doses of 8,16 and $32 \mathrm{Mg} \mathrm{ha}^{-1}$, respectively.

Significant differences between the applied doses were also observed for $\mathrm{Mg}, \mathrm{Ca}+\mathrm{Mg}, \mathrm{Ca}, \mathrm{K}, \mathrm{C}, \mathrm{H}+\mathrm{Al}$. With this, regression analysis was applied to make it clearer the visualization of the data obtained as a function of the applied doses and canola planting.

The Table 4 shows the regression analyzes of the evaluated attributes, being easier to observe the significant interactions in relation to the applied doses.

Table 4. Equations for the doses of avian bed in an Eutrophic Red Latosol, Serranópolis do Iguaçu-PR.

\begin{tabular}{|c|c|c|}
\hline Attributes & Regression of amounts of avian bed & $\mathrm{R}^{2}$ \\
\hline $\mathrm{pH}$ in water & $\mathrm{y}=0.0007 \mathrm{x}^{2}-0.0158 \mathrm{x}^{\mathrm{ns}}+5.561^{\mathrm{ns}}$ & 0.44 \\
\hline $\mathrm{pH} \mathrm{CaCl}{ }_{2}$ & $y=0.001 x^{2}-0.0271 x^{* *}+5.1617^{* *}$ & 0.76 \\
\hline pH SMP & $y=-0.0008 x^{2}+0.032 x^{* *}+5.8993^{n s}$ & 0.59 \\
\hline $\mathrm{H}+\mathrm{Al}\left(\mathrm{cmol}_{\mathrm{c}} \mathrm{dm}^{-3}\right)$ & $\mathrm{y}=0.0028 \mathrm{x}^{2}-0.1125 \mathrm{x}^{* *}+5.3441^{\mathrm{ns}}$ & 0.62 \\
\hline $\mathrm{P}\left(\mathrm{mg} \mathrm{dm} \mathrm{m}^{-3}\right)$ & $\mathrm{y}=0.0311 \mathrm{x}^{2}-0.8003 \mathrm{x}^{\mathrm{ns}}+47.529^{\mathrm{ns}}$ & 0.40 \\
\hline $\mathrm{C}\left(\mathrm{g} \mathrm{dm}^{-3}\right)$ & $y=-0.0246 x^{2}+0.704 x^{n s}+10.609^{n s}$ & 0.53 \\
\hline $\mathrm{K}\left(\mathrm{cmol}_{\mathrm{c}} \mathrm{dm}^{-3}\right)$ & $y=-0.0004 x^{2}+0.0189^{* *} x+0.4432^{* *}$ & 0.69 \\
\hline $\mathrm{Ca}\left(\mathrm{cmol}_{\mathrm{c}} \mathrm{dm}^{-3}\right)$ & $y=0.0052 x^{2}-0.1624 x^{* *}+5.4948^{* *}$ & 0.74 \\
\hline $\mathrm{Ca}+\mathrm{Mg}\left(\mathrm{cmol}_{\mathrm{c}} \mathrm{dm}^{-3}\right)$ & $y=0.0077 x^{2}-0.2316 x^{* *}+7.6281^{* *}$ & 0.75 \\
\hline $\operatorname{Mg}\left(\mathrm{cmol}_{\mathrm{c}} \mathrm{dm}^{-3}\right)$ & $\mathrm{y}=0.0025 \mathrm{x}^{2}-0.0692 \mathrm{x}^{\mathrm{ns}}+2.1333^{\mathrm{ns}}$ & 0.59 \\
\hline $\mathrm{S}\left(\mathrm{mg} \mathrm{dm}^{-3}\right)$ & $\mathrm{y}=0.0078 \mathrm{x}^{2}-0.339 \mathrm{x}^{\mathrm{ns}}+20.066^{\mathrm{ns}}$ & 0.07 \\
\hline
\end{tabular}

Note. $* *$ Significant by t-test $(\mathrm{p}<0.05)$; Ns: not significant. 
Only the attributes $\mathrm{pH}_{\mathrm{CaCl} 2}, \mathrm{~K}, \mathrm{Ca}$ and $\mathrm{Ca}+\mathrm{Mg}$ had a significant dose and attribute relationship. Thus, the graphs of the interactions are shown in Figures 1A, 1B, 1C, and 1D.

A

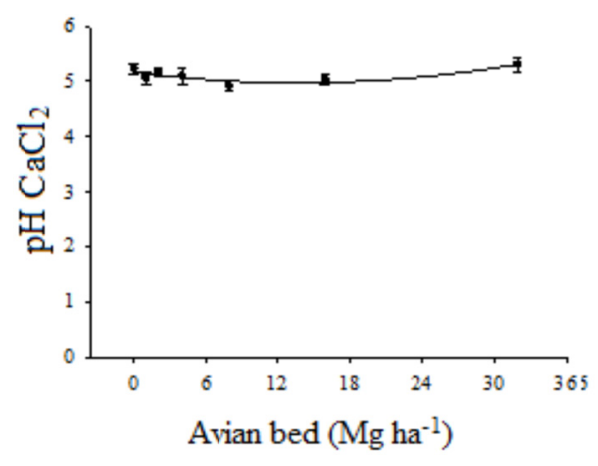

$\mathrm{C}$

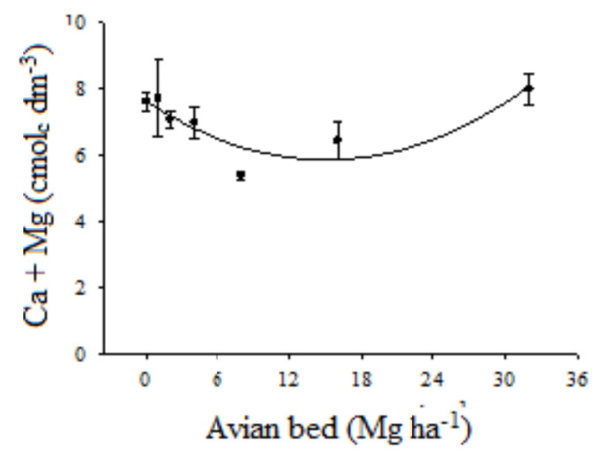

B

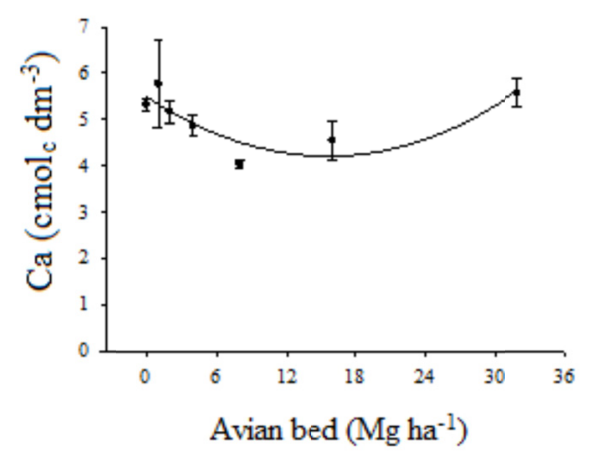

$\mathrm{D}$

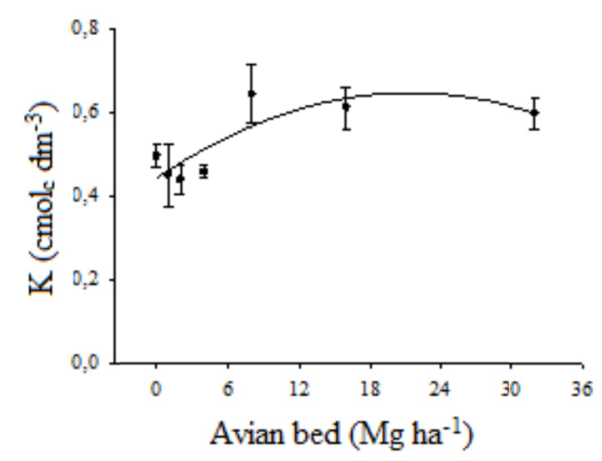

Figure 1. Mean values and regression of $\mathrm{pH}$ levels in $\mathrm{CaCl}_{2}(\mathrm{~A})$, calcium (B), calcium + magnesium $(\mathrm{C})$ and potassium (D), as a function of avian bed doses, in an Eutrophic Red Latosol, Serranópolis do Iguaçu-PR

Figure $1 \mathrm{~A}$ shows the regression analysis for $\mathrm{pH}_{\mathrm{CaCl} \text {. }}$. High concentrations of the cations such as $\mathrm{K}^{+}$, $\mathrm{Ca}^{2+}$ and $\mathrm{Mg}^{2+}$ can be attributed to the cation exchange capacity of the soil, increasing this exchange, increasing the levels.

In works by Scherer et al. (2007), Lima et al. (2007), and Pinto et al. (2012) observed that there were no significant changes in $\mathrm{pH}$ after application of organic matter. It is necessary the presence of organic acids or a low $\mathrm{pH}$ in the soil, so that phosphorus fixation is reduced by the soil and increasing its availability (Branco, Murgel, \& Cavinatto, 2001). Thus, it is possible to observe, in this work, that the doses of phosphorus did not change significantly, resulting from a low acid $\mathrm{pH}$ and greater fixation of the same.

Research carried out by Santos et al. (2004) showed reductions in potential acidity, in relation to the addition of chicken litter compound, also in Red Latosol, and designated the increase in $\mathrm{pH}$ to increase the levels of exchangeable cations in the soil. In the present work a significant increase of the $\mathrm{pH}$ was observed, which can be explained by the initial $\mathrm{pH}$ being not very low and the fixation of the phosphorus by the soil does not occur and then it is not in an available condition, so that the $\mathrm{pH}$ analysis does not change significantly.

Regression analyzes of $\mathrm{Ca}^{2+}$ levels are presented in Figure 1B. The variation of the contents of this attribute has a positive influence of the doses of avian bed, that is, higher doses of avian bed result in higher levels of $\mathrm{Ca}^{2+}$. Studies by Moreti et al. (2007) obtained $\mathrm{Ca}^{2+}$ levels of 75.87 and $44.87 \mathrm{mmolc} \mathrm{dm}^{-3}$ at doses of $14 \mathrm{t} \mathrm{ha}^{-1}$ of chicken manure, respectively, while in the present study, values of $4.5 \mathrm{cmolc} \mathrm{dm}^{-3}$, presenting similarity of the data.

The regressions performed for the mean levels of Potassium $(\mathrm{K})$ and $\mathrm{Ca}^{2+}+\mathrm{Mg}^{2+}$ attributes are presented in Figures $1 \mathrm{C}$ and 1D. When comparing the data evaluated separately, it is observed that the $\mathrm{Ca}^{2+}$ contents are higher than the $\mathrm{Mg}^{2+}$ contents, and this is due to the $\mathrm{Mg}^{2+}$ ions presenting a larger diameter than the $\mathrm{Ca}^{2+}$ ions, 
being less retained in the solution alone. The capacity of cation exchange in the soil adsorption sites is intensified by the increase in the number of negative charges, increasing the reactions between soil colloids and the basic cations, which are easily available to the soil solution (Silva \& Bohnen, 2006).

In relation to $\mathrm{K}$, it is observed that the application of combined litter doses to canola cultivation has influence on the results, showing that intermediate doses $\left(12\right.$ and $\left.18 \mathrm{Mg} \mathrm{ha}^{-1}\right)$ provided an increase in the content of this nutrient in the analyzed soil . Studies by Falleiro et al. (2003) report the accumulation of $\mathrm{K}^{+}$in the superficial layer near the region of application of the fertilizer. Moreti et al. (2007), also on a Red Latosol, evaluated soil chemical attributes, such as phosphorus, organic matter, $\mathrm{pH}$, Potassium, Calcium, Magnesium, among others. Potassium content of 5.54 and $5.51 \mathrm{mmolc} \mathrm{dm}^{-3}$ in depth from 0 to $20 \mathrm{~m}$, also in Red Latosol.

It was observed in studies conducted by Scherer et al. (2007) that when there is an increase in plant nutrients, soil quality improves, reducing erosion and increasing water retention, resulting in a better biological quality of the soil due to the effective increase in C and N levels (N) (Bayer, Martin-Neto, Mielniczuk, \& Pavinat, 2004). Studies performed by Pinto et al. (2012) obtained similar curves in their data for a Red Latosol submitted to turkey poultry bed doses also in intermediate values of $16.5 \mathrm{Mg} \mathrm{ha}^{-1}$, which resulted in higher values of C (4.5 $\left.\mathrm{mg} \mathrm{ha}^{-1}\right)$. The total organic carbon is the fraction most sensitive to the management, being influenced by the application of organic waste (Conte, 2011).

When applying urban litter to a Red Latosol, Strojaki et al. (2013) evaluated the soil Mg content with urban waste application, obtaining values of 3.2 to $4.3 \mathrm{cmolc} \mathrm{dm}^{-3}$, depending on the depth evaluated. Although the organic matter used did not have the same origin, the contents presented similarity.

The decomposition of organic residues results in water-soluble compounds that form complexes with acid-reacting cations in the soil solution, causing anions to be released that precipitate aluminum and consequently raise the $\mathrm{pH}$ (Petrere \& Anghinoni, 2001).

It is possible to visualize a change in soil nutrition when the sulfur content is observed. Sleep initially contained $3.54 \mathrm{mg} \mathrm{dm}^{-3}$ (or $8.5 \mathrm{~kg} \mathrm{ha}^{-1}$ by conversion: $\mathrm{mg} \mathrm{dm}^{-3} \times 2=\mathrm{kg} \mathrm{ha}^{-1}$ ), the aviary bed had $0.85 \%$ (resulting in $50 \mathrm{~kg}$ $\mathrm{ha}^{-1}$ or $4.25 \mathrm{mg} \mathrm{dm}^{-3}$ ), with the application of the aviary bed and after canola cultivation, the soil had the highest content of $25 \mathrm{mg} \mathrm{dm}^{-3}\left(50 \mathrm{~kg} \mathrm{ha}^{-1}\right)$ a very high amount while at the lowest point had $13.5 \mathrm{mg} \mathrm{dm}^{-3}\left(27 \mathrm{~kg} \mathrm{ha}^{-1}\right)$. Even with the cultivation of canola, the degradation was not so great that the soil was in conditions of new fertilization for the next crop. The aviary bed was quite efficient at aggregating nutrients into the soil.

\section{Conclusions}

The doses of avian litter in succession to canola planting have a significant influence on the levels of Potassium, Calcium, Calcium + Magnesium and $\mathrm{pH}$ measured in $\mathrm{CaCl}_{2}$. Although the other attributes are not statistically different, there are also variations. The aviary bed, in this work, was a fertilizer of high efficiency, causing a good quality of the soil and not losing the quality after the planting of the canola.

\section{References}

Bayer, C., Martin-Neto, L., Mielniczuk, J., \& Pavinat A. (2004). Armazenamento de carbono em frações lábeis da matéria orgânica de um latossolo vermelho sob plantio direto. Pesquisa Agropecuária Brasileira, Brasilia, Distrito Federal, 39(7), 677-683. https://doi.org/10.1590/S0100-204X2004000700009

Branco, S. M., Murgel, P. H., \& Cavinatto, V. M. (2001). Compostagem: Solubilização biológica de rocha fosfática na produção de fertilizante organomineral. Engenharia Sanitária e Ambiental, 6, 115-122.

Conte, O. (2011). Densidade, agregação e frações de carbono de um argissolo sob pastagem natural submetida a níveis de ofertas de forragem por longo tempo. Revista Brasileira de Ciência do Solo, Viçosa, 35(2), 579-587. https://doi.org/10.1590/S0100-06832011000200027

Costa, A. M., Borges, E. N., Silva, A. N., \& Guimarães, E. C. (2009). Potencial de recuperação física de um latossolo vermelho, sob pastagem degradada, influenciado pela aplicação de cama de frango. Ciência e Agrotecnologia, 33, 1991-1998. https://doi.org/10.1590/S1413-70542009000700050

Falleiro, R. M., Souza, C. M., Silva, C. S. W., Sediyama, C. S., Silva, A. A., \& Fagundes, J. L. (2003). Influência dos sistemas de preparo nas propriedades químicas e físicas do solo. Revista Brasileira de Ciência do Solo, 27, 1097-1104. https://doi.org/10.1590/S0100-06832003000600014

Ferreira, D. F. (2008). Sisvar: Um programa para análises e ensino de estatística. Revista Científica Symposium, $6(2), 36-41$.

Gomes, F. P. (2000). Curso de estatística experimental (14th ed., p. 477). Piracicaba: Degaspari. 
IBGE (Instituto Brasileiro de Geografia e Estatística). (2017). Retrieved from http://www.ibge.gov.br

Krob, A. D. (2011). Propriedades químicas de um argissolo tratado sucessivamente com composto de lixo urbano. Ciência Rural, Santa Maria, 41(3), 433-439. https://doi.org/10.1590/S0103-84782011005000017

Lima, J. J., Mata, J. de D. V da, Neto, R. P., \& Scapim, C. A. (2007). Influência da adubação orgânica nas propriedades químicas de um Latossolo Vermelho distrófico e na produção de matéria seca de Brachiaria brizantha cv. Marandu. Maringá, 29, 715-719. https://doi.org/10.4025/actasciagron.v29i5.754

Lovato, T., Mielniczuk, J., Bayer, C., \& Vezzani, F. R. (2004). Adição de carbono e nitrogênio e sua relação com os estoques no solo e com o rendimento do milho em sistemas de manejo. Revista Brasileira de Ciência do Solo, 28, 175-187. https://doi.org/10.1590/S0100-06832004000100017

MAPA (Ministério da Agricultura, Pecuária e Abastecimento). (2017). Retrieved from http://www.agricultura. gov.br/animal/especies/aves

Melo, A. V., Galvão, J. C. C., Braun, H., Santos, M. M., Coimbra, R. R., Silva, R. R., \& Reis, W. F. (2011). Extração de nutrientes e produção de biomassa de aveia-preta cultivada em solo submetido a dezoito anos de adubação orgânica e mineral. Semina: Ciências Agrárias, Londrina, 32(2), 411-420. https://doi.org/ $10.5433 / 1679-0359$

Moreti, D., Alves, M. C., Valério Filho, W. V., \& Carvalho, M. de P. e. (2007). Atributos químicos de um latossolo vermelho sob diferentes sistemas de preparo, adubações e plantas de cobertura. Revista Brasileira de Ciencia do Solo, 31(1), 167-175. https://doi.org/10.1590/S0100-06832007000100017

Petrere, C., \& Anghinoni, I. (2001). Alteração de atributos químicos no perfil do solo pela calagem superficial em campo nativo. Revista Brasileira de Ciência do Solo, Viçosa, 25, 885-895. https://doi.org/10.1590/ S0100-06832001000400011

Pinto, F. A., Santos, F. L. dos, Terra, F. D., Ribeiro, D. O., Souza, R. R. J., Souza, E. D. de, Carneiro, M. A. C., \& Paulino, H. B. (2012). Atributos de solo sob pastejo rotacionado em função da aplicação de cama de peru. Pesquisa Agropecuaria Tropical, 42(3), 254-262. https://doi.org/10.1590/S1983-40632012000300002

Santos, C. C., Bellingieri, P. A., \& Freitas, J. C. (2004). Efeito da aplicação de compostos orgânicos de cama de frango nas propriedades químicas de um latossolo vermelho escuro cultivado com sogro granífero [Sorghum bicolor (L.) Moench]. Cientifica, Jaboticabal, 32(2), 134-140.

Scherer, E. E., Baldissera, I. T., \& Nesi, C. N. (2007). Propriedades químicas de um latossolo vermelho sob plantio direto e adubação com esterco de suínos. Revista Brasileira de Ciencia do Solo, 31(1), $123-131$. https://doi.org/10.1590/S0100-06832007000100013

Silva, A. A., Costa, A. M. da, Lana, R. M. Q., \& Lana, A. M. Q. (2012). Recycling of nutrients with application of organic waste in degraded pasture. Engenharia Agricola, Jaboticabal, 32(2), $405-414$. https://doi.org/10.1590/S0100-69162012000200020

Silva, L. S., \& Bohnen, H. (2006). Relações entre nutrientes na fase sólida e solução de um latossolo durante o primeiro ano da instalação dos sistemas plantio direto e convencional. Ciência Rural, Santa Maria, 36(4), 1164-1171. https://doi.org/10.1590/S0103-84782006000400019

Strojaki, T. V., Silva, V. R. da, Somavilla, A., Ros, C. O. da, \& Moraes, M. T. de. (2013). Atributos químicos do solo e produtividade de girassol e milho em função da aplicação de composto de lixo urbano. Pesquisa Agropecuaria Tropical, 43(3), 278-285. https://doi.org/10.1590/S1983-40632013000300002

\section{Copyrights}

Copyright for this article is retained by the author(s), with first publication rights granted to the journal.

This is an open-access article distributed under the terms and conditions of the Creative Commons Attribution license (http://creativecommons.org/licenses/by/4.0/). 